\title{
Wsparcie emocjonalne dla rodziców dzieci głuchych i stabosłyszących w ramach terapii surdologopedycznej
}

\section{Emotional support for parents of deaf and hard-of-hearing children within speech-language therapy for the deaf}

\author{
Joanna Kobosko \\ Instytut Fizjologii i Patologii Słuchu, Światowe Centrum Słuchu, Klinika Rehabilitacji, Warszawa/Kajetany \\ Adres autora: Joanna Kobosko, Światowe Centrum Słuchu, Klinika Rehabilitacji, ul. Mokra 17, Kajetany, \\ 05-830 Nadarzyn, e-mail: j.kobosko@ifps.org.pl
}

\begin{abstract}
Streszczenie
W artykule podjęto zagadnienie wsparcia emocjonalnego dla rodziców dzieci głuchych i słabosłyszących w ramach terapii surdologopedycznej. Składa się on z 4 części. W części pierwszej omówiono, czym jest wsparcie emocjonalne, jego znaczenie i źródła w odniesieniu do rodziców dzieci głuchych. Część druga zawiera wyniki badań jakościowych pilotażowych na temat tego, „czym jest dla mnie wsparcie?” i „kiedy czuję się wspierana?”, przeprowadzonych z udziałem terapeutek mowy. W części trzeciej omówiono psychologiczne aspekty udzielania wsparcia emocjonalnego rodzicom dzieci głuchych przez logopedów (i innych specjalistów), do których należą: a) osobowa relacja terapeuty mowy i rodzica, b) role i zasady tworzące ramy dla terapii surdologopedycznej, a także dla udzielanego rodzicom wsparcia, c) „granice” w relacji terapeuta mowy i rodzic, d) efektywne komunikowanie się z drugą osobą, e) niezaprzeczanie głuchocie dziecka i jej konsekwencjom, a także uczuciom doświadczanym przez rodzica: bezsilności, smutku, złości i innych, f) właściwe korzystanie z własnych doświadczeń i wiedzy przez terapeutów mowy. W czwartej części zaprezentowane zostały przykłady sytuacji trudnych, z którymi spotykać się mogą logopedzi, a także pokazano możliwości różnych interwencji, jakie wykorzystywać mogą terapeuci mowy wobec rodziców dzieci głuchych w ramach prowadzonej terapii surdologopedycznej dzieci.
\end{abstract}

Podsumowaniem jest m.in. wniosek, że terapeuci mowy prowadzący terapię logopedyczną dzieci głuchych i słabosłyszących powinni mieć możliwość psychoedukacji i szkolenia w zakresie świadomego i efektywnego emocjonalnego wspierania rodziców, którzy odgrywają ogromną rolę w terapii. Autorka postuluje wprowadzenie możliwości superwizji czy uczestnictwa w tzw. grupach balintowskich dla surdologopedów oraz logopedów pracujących z dziećmi o innych zaburzeniach i ich rodzicami, celem wsparcia tej grupy zawodowej w tworzeniu optymalnej dla rodziców i ich dzieci relacji terapeuty mowy i rodzica.

Słowa kluczowe: wsparcie emocjonalne $\bullet$ rodzic $\bullet$ dziecko głuche $\bullet$ terapeuta mowy (logopeda) • relacja terapeuta mowy - rodzic dziecka głuchego • terapia surdologopedyczna • głuchota prelingwalna

\begin{abstract}
This paper addresses an issue of emotional support for parents of deaf and hard-of-hearing children provided within the framework of speech-language therapy for the deaf. It consists of 4 parts. The first one discusses what the emotional support is, its meaning and sources in relation to parents of deaf children. The second part includes results of the pilot qualitative studies on 'What is the emotional support for me?' and 'When do I feel supported', conducted with the participation of speech-language therapists. The third part addresses psychological aspects of providing the emotional support for parents of deaf children by speech-language therapists and other specialists. This includes: a) personal relation between therapists and parents, b) roles and principles creating the framework for speech-language therapy and for the support given to parents, c) 'borders' in the relationship between speech therapists and parents, d) effective communication with another person, e) not to negate child's deafness and its consequences as well as parent's feelings such as helplessness, sadness, anger, f) appropriate use of speechtherapist's own experience and knowledge. The fourth part presents examples of difficult situations encountered by speechlanguage therapists in speech-language therapy for deaf children and various possibilities of intervention available for speech therapists in relation to parents of deaf children.
\end{abstract}

Summarization includes a conclusion that speech therapists conducting speech-language therapy for deaf and hard-of-hearing children should have an opportunity of psychological education and training with regard to providing an informed and effective emotional support to their parents, who are a crucial element of a successful therapy. Author postulates introducing 
the possibility of supervision or participating in a Balint Group for speech-language therapists of the deaf and those who work with children with other dysfunctions and their parents, in order to support this occupational group in establishing optimal relationship between speech therapists and parents for the benefit of parents and their children.

Key words: emotional support $\bullet$ parents $\bullet$ deaf child $\bullet$ speech-language therapists $\bullet$ relationship between speech-language therapists and parents of a deaf child $\bullet$ speech-language therapy for the deaf $\bullet$ prelingual deafness

\section{Wprowadzenie}

Wsparcie emocjonalne - w ogólnym ujęciu - polega na „przekazaniu w toku wymiany [społecznej] emocji o charakterze podtrzymującym, uspokajającym, wyrażających troskę i pozytywne zainteresowanie osobą wspieraną (komunikaty werbalne i niewerbalne typu lubimy cię, nie poddawaj się, jesteśmy z tobą, dasz sobie radę itp.)" [1, s. 17-18]. Wsparcie to pozwala na stworzenie poczucia przynależności, sprzyja dobrej samoocenie, nadziei, poprawia samopoczucie. Okazuje się, że jest oczekiwane nawet wtedy, gdy bezpośrednio nie rozwiązuje istniejącego problemu [2]. Wsparcie emocjonalne stanowi formę wsparcia społecznego, a więc tego, które zachodzi w relacjach międzyludzkich, można je zarówno otrzymać, jak i dać drugiej osobie.

Umiejętność korzystania ze wsparcia emocjonalnego, jak i innych odmian wsparcia społecznego, zwłaszcza w sytuacjach trudnych, związanych $\mathrm{z}$ dużym nasileniem stresu, kryzysowych czy traumatycznych, należy do zasobów danej osoby, sprzyjających procesowi radzenia sobie ze stresem, kryzysem czy traumą psychiczną. Przedstawiciele transakcyjnej koncepcji stresu i radzenia sobie $\mathrm{z}$ nim traktują wsparcie emocjonalne jako jedną ze strategii $c o$ ping $[3,4]$.

Dla rodziców dzieci głuchych ${ }^{1}$ i słabosłyszących sięganie po szeroko rozumiane wsparcie emocjonalne, zwłaszcza udzielane profesjonalnie $\mathrm{w}$ ramach różnych form interwencji psychologicznych, w tym psychoterapii, jest niezwykle ważne, lecz jednocześnie - jak pokazuje praktyka kliniczna - bardzo trudne [5-8]. Specjaliści zaangażowani w rehabilitację słuchu i mowy dziecka (wraz z jego rodzicami), w tym m.in. terapeuci mowy (logopedzi), powinni mieć świadomość, jak tego wsparcia udzielać, aby $\mathrm{w}$ efekcie sprzyjało ono rodzicom, a tym samym ich dzieciom, by było ono udzielane świadomie i profesjonalnie, $\mathrm{z}$ zachowaniem zasad obowiązujących $\mathrm{w}$ relacji pomagania, w tym granic wyznaczonych pełnioną rolą zawodową.

Rodzice dzieci głuchych komunikaty „o pomoc i wsparcie” kierują niejednokrotnie do logopedów prowadzących terapię ich dziecka, a czynią to świadomie w różnym stopniu, bardziej lub mniej bezpośrednio, bywa że „poprzez problem dziecka”. W przekonaniu bowiem wielu rodziców dzieci głuchych (niepełnosprawnych) to ich dziecko potrzebuje pomocy i wsparcia, a nie oni sami [9]. Ci specjaliści należą dość często do grona bardzo ważnych osób w życiu rodziców i dziecka, o czym mówią zwłaszcza matki, nawet po wielu latach $[10,11]$. Wobec wysokich oczekiwań związanych ze wsparciem kierowanych przez rodziców dzieci głuchych i słabosłyszących wobec logopedów, także oni niejednokrotnie zadają sobie pytanie, jak wspierać emocjonalnie rodziców, by udzielane wsparcie było z korzyścią dla wspieranych, a także pozostawało w zgodzie $\mathrm{z}$ interesami wspierających oraz rolą zawodową logopedy, umiejętnościami i ograniczeniami w tym zakresie.

\section{Cel pracy}

Celem artykułu jest przybliżenie zagadnienia wsparcia emocjonalnego dla rodziców dzieci głuchych, udzielanego im m.in. w relacji z terapeutą mowy. Przyjęto, że optymalne warunki dla tego rodzaju wsparcia stwarza: a) osobowa relacja terapeuta mowy - rodzic dziecka głuchego, b) taka relacja, w której przestrzegane są zasady wynikające $\mathrm{z}$ jej charakteru i zawartego tzw. kontraktu między stronami, a tym samym pozwalajacca na utrzymanie granic, c) relacja, w której stosowane są przez terapeutę mowy zasady efektywnego komunikowania się z drugą osobą, tj. rodzicem dziecka głuchego, d) relacja, w której osoba udzielająca emocjonalnego wsparcia (terapeuta mowy) nie zaprzecza istnienia problemu (głuchocie, niepełnosprawności dziecka) oraz doświadczanym przez drugą osobę (rodzica) stanom psychicznym i emocjom: cierpieniu, bezsilności, niemocy czy złości, a także e) terapeuta mowy (czy inny terapeuta) ma dostęp do własnych zasobów związanych z doświadczaniem i udzielaniem emocjonalnego wsparcia. Odwołano się do doświadczeń logopedów (kobiety) ukazujących, jakie znaczenia nadają emocjonalnemu wsparciu, jak i kiedy go doświadczają (pilotażowe badania jakościowe).

Artykuł zawiera część praktyczną - przykłady sytuacji trudnych spotykanych w praktyce surdologopedycznej (i nie tylko) oraz wybrane możliwe sposoby interwencji, jakie mogą wykorzystać terapeuci mowy w relacji z rodzicem dziecka głuchego. Interwencje te mają sprzyjać dawaniu wsparcia emocjonalnego w sposób optymalny, a więc wspierający rodziców ku osobowemu rozwojowi (a nie obronie przed lękiem czy cierpieniem).

\section{Wsparcie emocjonalne a rodzice dzieci głuchych i słabosłyszących}

Wsparcie emocjonalne, choć czasem trudne do oddzielenia od innych form wsparcia społecznego, gdyż często $\mathrm{z}$ nimi współwystepuje, jest niezwykle potrzebne rodzicom dzieci głuchych. Jak to wyraziła jedna z matek: „Trzeba mieć wsparcie w innych, w rodzinie, w znajomych, w mężu, we wszystkich" [11, s. 231]. Wsparcie społeczne pełni rolę mediującą względem chronicznego stresu doświadczanego

\footnotetext{
${ }^{1 .}$ Określenie „dziecko głuche” obejmuje dzieci, które wg klasyfikacji audiologicznych (np. BIAP) posiadają znaczny lub głęboki ubytek słuchu, co odpowiada przyjętemu w naukach społecznych definiowaniu osoby głuchej jako tej, która bez urządzeń wzmacniających słyszenie nie odbiera przy uchu głośnej mowy, a więc jest głucha (ang. deaf)
} 
przez rodziców dzieci głuchych, którego doświadczanie jest związane z percepcją mniejszego wsparcia emocjonalnego [12]. Satysfakcjonujące wsparcie uzyskało w swojej opinii $51 \%$ matek dzieci $z$ wadą słuchu w badaniach przeprowadzonych kilka lat temu przez Baran [11]. Jak mówi w podsumowaniu autorka, wiele matek przyznaje, że dzięki wsparciu otrzymywanemu od specjalistów, m.in. w poradniach i ośrodkach rehabilitacji, lepiej radzi sobie z problemami, które dotyczą nie tylko dziecka, lecz także ich samych i innych sfer życia [11].

$\mathrm{Na}$ temat różnych form wsparcia, jakiego potrzebują rodzice dzieci $\mathrm{z}$ wadą słuchu, przeprowadzono anonimowo badania ankietowe w Kanadzie [13]. W odniesieniu do tej grupy rodziców wyodrębnione zostały trzy rodzaje wsparcia: wsparcie informacyjne, społeczno-emocjonalne i wsparcie edukacyjne. Pytano rodziców i opiekunów m.in. o źródła wsparcia, a więc od kogo i w jakim zakresie oni sami otrzymują wsparcie. Okazało się, że pierwsze miejsce zajęli inni rodzice dzieci z podobnym problemem, co zresztą nie zaskakuje [14,15]. Drugie miejsce otrzymali specjaliści zaangażowani w rehabilitację i edukację dziecka. W dalszej kolejności znalazły się organizacje dla rodzin dzieci głuchych i słabosłyszących, dziadkowie i dalsza rodzina. Najbliższa rodzina, w tym współmałżonkowie, mimo że stanową dla rodziców bardzo oczekiwane i ważne źródło wsparcia, pozostawali na ostatnim miejscu. Z nielicznych bowiem badań, np. przeprowadzonych przez Michelsen [za: 7], a także z kontaktów zawodowych autorki $\mathrm{z}$ rodzicami podczas prowadzonych warsztatów i grup wsparcia dla rodziców dzieci z wadą słuchu wynika, że niejednokrotnie negatywnym zmianom ulega jakość relacji małżeńskiej. Przeciwne rezultaty do powyższych - w zakresie otrzymywanego źródła wsparcia, jeśli chodzi o współmałżonków rodziców dzieci z wadą słuchu, otrzymała Borowicz [16]. W badaniach tej autorki współmałżonek znajduje się na pierwszym miejscu jako źródło otrzymywanego wsparcia. Rozbieżność rezultatów wynikać może z wielu przyczyn, m.in. kontekstu społeczno-kulturowego, w jakim żyją rodzice dzieci z wadą słuchu w Kanadzie i Polsce, w którym to znacząco odmienne jest przyzwolenie na konfrontację z niespełnionymi oczekiwaniami odnośnie relacji małżeńskiej, a co za tym idzie - z frustracją potrzeby wsparcia, nie tylko emocjonalnego, doświadczanej przez matki w relacji z ojcem dziecka głuchego (niepełnosprawnego).

\section{Relacja terapeuty mowy $\mathrm{z}$ rodzicami dziecka głuchego jako relacja pomagania}

Relacja pomagania jest z natury swej relacją "pochyłą”, niesymetryczną, a więc taką, w której osoba pomagająca udziela pomocy, a druga osoba lub osoby o tę pomoc się zwracają [17]. W relacji rodzica dziecka głuchego $\mathrm{z}$ terapeutą mowy, prowadzącym terapię surdologopedyczną dziecka, ten ostatni występuje w roli osoby pomagającej. To samo odnosi się do innych specjalistów: lekarzy, psychologów, pedagogów, protetyków słuchu itp. „Związek między osobą pomagającą i wspomaganą jest ściśle określony. Pomaganie to relacja skupiona na osobie wspomaganej i jej problemach" [17, s. 16]. Relacja pomagania - jak w omawianym przykładzie - nosi niejednokrotnie cechy relacji wspomagającej rozwój osoby (rodzica), „w której intencją jednej ze stron jest docenianie, szersze wyrażenie i bardziej funkcjonalne wykorzystanie (...) zasobów wewnętrznych jednostki” [18, s. 68].

Coraz częściej znaleźć można doniesienia $\mathrm{z}$ badań prowadzonych nad efektywnością treningów doskonalących umiejętności wspierania rodziców dzieci z wadą słuchu przez pracujących i współpracujących $z$ nimi różnych specjalistów [19]. Wynika z nich m.in., że około dwóch trzecich osób uczestniczących w powyższych badaniach nigdy nie rozmawia lub czyni to rzadko $\mathrm{z}$ rodzicami na temat objawów depresji i lęku, które mogą utrudniać (ograniczać) skuteczność prowadzonej interwencji, np. terapii surdologopedycznej. Stany i zaburzenia depresyjne należą do najczęściej spotykanych u rodziców dzieci niepełnosprawnych, w tym dzieci głuchych, chociażby w związku $\mathrm{z}$ doświadczaniem przez nich procesu żałoby przeżywanej wskutek utraty dziecka słyszącego, zdrowego i normalnego $[20,21]$. Położenie osoby udzielającej wsparcia emocjonalnego rodzicowi w depresji w ramach terapii surdologopedycznej (lub innej) jest jeszcze bardziej skomplikowane ze względu na to, że osoba w depresji m.in. „dyskredytuje wsparcie społeczne" [1, s. 23].

Sytuację opisaną powyżej wyjaśnia częściowo brak pewności siebie, jakiego doświadczają specjaliści pracujący w obszarze rehabilitacji słuchu i mowy dzieci z zaburzeniami słuchu, jeśli chodzi o rozpoznawanie symptomów depresji i lęku, a następnie umiejętne komunikowanie o tym rodzicom. Specjaliści ci czują się także niepewni co do sposobu, w jaki konfrontować rodziców z zaprzeczaniem różnych faktów dotyczących dziecka i ich samych czy też z doświadczanymi przez rodziców silnymi emocjami [19].

W relacji pomagania, także tej, jaką tworzy terapeuta mowy z rodzicem dziecka głuchego, odgrywają rolę własne doświadczenia i umiejętne korzystanie $\mathrm{z}$ tej wiedzy o sobie. Do własnych zasobów terapeuty mowy (czy innego specjalisty w sferze rehabilitacji słuchu i mowy) zaliczyć można taką własność, jaką jest styl prowadzenia interwencji wobec rodziców i dziecka, który modyfikuje relację pomagania. $\mathrm{W}$ jednym $\mathrm{z}$ nielicznych badań poświęconych relacjom, jakie tworzą specjaliści wczesnej interwencji $\mathrm{z}$ matkami dzieci z zaburzeniami (w sferze motorycznej) [22], opisywano je, uwzględniając dwa wymiary: satysfakcję matek i poczucie kontroli (związanej np. z podejmowanymi przez matki decyzjami) w relacji $z$ terapeutą. Uzyskano rezultat świadczący o tym, że niższemu poziomowi stresu rodzicielskiego, a także (większemu) poczuciu kompetencji macierzyńskich sprzyja relacja o charakterze „współpracującym” (wysoka satysfakcja matki i wysokie poczucie kontroli) w sposób znacząco większy niż ma to miejsce w relacji typu „zdystansowanego” (niska satysfakcja matki i niskie poczucie kontroli). Nie było jednakże różnic w odniesieniu do doświadczanego stresu i kompetencji macierzyńskich między relacją matka - terapeuta typu „współpracującego" a relacją o charakterze „tradycyjnym” (wysoka satysfakcja matki i niskie poczucie kontroli) czy „niezgodnym” (niska satysfakcja matki i wysokie poczucie kontroli). Wynika stąd wniosek, że specjaliści potrafiący stworzyć z matkami relację „współpracującą" czy „tradycyjną” najprawdopodobniej potrafią też umiejętnie i kompetentnie wspierać emocjonalnie rodziców dzieci będących u nich w terapii. 
Tabela 1. Wsparcie emocjonalne - znaczenia (kategorie) nadawane przez terapeutów mowy (kobiety $n=39$ ) wraz z częstością ich występowania w badanej grupie

Table 1. Emotional support - meanings (categories) attributed by speech therapists (females $n=39$ ) and the frequency of their occurrence in the studied group

\section{Znaczenia nadawane wsparciu emocjonalnemu: „Czym jest dla mnie psychiczne wsparcie?" $n=39(100 \%)$}

[1] Poznanie problemów - 1 (2,5\%) [2] Uważne wysłuchanie, pozwolenie na opowiedzenie, słuchanie - 12 (30,7\%)

[3] Pomoc w szukaniu rozwiązania, pomoc drugiej osobie, podpowiedź dotycząca możliwych rozwiązań, zaproponowanie konkretnych pomystów na rozwiązanie trudnej sytuacji, udzielenie pomocy, , pomocna dłoń”, określenie granic pomocy, gotowość pomocy, próba pomocy, pomoc w samodzielnym działaniu - 35 (89,7\%) [4] Wskazanie posiadanych przeze mnie zasobów - 1 (2,5\%)

[5] Ukierunkowanie, dawanie wskazówek, naprowadzanie, rada, podpowiedzi, instrukcja, wskazówki, wyjaśnienie - 9 (23,1\%)

[6] Rozwiązanie problemu, plan działania - 2 (5\%) [7] Pokazanie wartości podejmowanego wysitku - 1 (2,5\%)

[8] Pokazanie ewentualnego postępu w sprawie - 1 (2,5\%) [9] Bycie obok w trudnych momentach, nie musi nic mówić, ważne, że ta osoba jest, „Bądź ze mną” - 4 (10,2\%) [10] Można na tę osobę liczyć, mogę liczyć na pomoc - 2 (5\%) [11] Osoba wspierająca radzi sobie z moimi negatywnymi silnymi emocjami - 1 (2,5\%) [12] Interakcja z drugą osobą, wspólne działanie, wspólne przemyślenie sytuacji - 4 (10,2\%) [13] Zainteresowanie drugą osobą - 1 (2,5\%) [14] Empatia - 4 (10,2\%)

[15] Zrozumienie - 12 (30,7\%) [16] Wyrozumiałość - 1 (2,5\%) [17] Współczucie - 2 (5\%) [18] Opieka - 4 (10,2\%)

[19] Zaufanie - 5 (12,8\%) [20] Rozmowa, możliwość przegadania różnych rozwiązań, szczera rozmowa - 7 (17,9\%] [21] Informacje,

przekazanie wiedzy - 7 (17,9\%) [22] Czas poświęcony, przeznaczony wyłącznie dla mnie - $3(7,7 \%)$ [23] Towarzyszenie - $1(2,5 \%)$

[24] Życzliwość - 2 (5\%) [25] Pocieszanie - 1 (2,5\%) [26] Poczucie bezpieczeństwa - 5 (12,8\%) [27] Akceptacja, akceptacja moich zalet i wad - 6 (15,4\%) [28] Uważność, życzliwa uwaga - 3 (7,7\%) [29] Przychylność - 1 (2,5\%) [30] Współodczuwanie - 1 (2,5\%) [31] Bliskość - 1 (2,5\%) [32] Kontakt - 1 (2,5\%)

Uwaga: Terapeutki mowy podawały zazwyczaj więcej niż 1 znaczenie (kategorię), które nadawane było przez nie „wsparciu psychicznemu", a więc całość nie sumuje się do 100\%.

Please note that speech therapists usually attributed more than 1 meaning (category) to the "emotional support", so total result in not $100 \%$.

Tabela 2. Wsparcie emocjonalne: „Kiedy czuję się wspierana?” - znaczenia (kategorie) nadawane przez terapeutów mowy (kobiety $n=21$ ) wraz z częstością ich występowania w badanej grupie

Table 2. Emotional support: "When do I feel supported" - meanings (categories) attributed by speech therapists (females $\mathrm{n}=21)$ and the frequency of their occurrence in the studied group

\section{Wsparcie emocjonalne: „Kiedy czuję się wspierana?”} $\mathrm{n}=21(100 \%)$

[1] Jeśli ktoś mnie rozumie (lub próbuje mnie zrozumieć), zrozumienie, gdy jestem rozumiana - 6 (28,6\%) [2] Jeśli ktoś mnie wysłucha, jeśli ktoś mnie słucha, a nie ocenia, gdy ktoś mnie wysłucha, gdy czuję się wysłuchana, ktoś potrafi, stara się wysłuchać - 10 (47,6\%) [3] Jeśli ktoś podpowie coś, czasem, dostaję sugestię, jak poradzić sobie z problemem, potrafi doradzić - $3(14,3 \%)$ [4] Jeśli ktoś jest ze mną „,nieinwazyjnie”, ktoś ze mną przebywa, gdy ktoś ze mną jest w trudnej sytuacji, nawet jeśli tylko trzyma za rękę (nie musi nic mówić), osoba jest blisko mnie, jest przy mnie, gdy ktoś jest blisko fizycznie - 7 (33,3\%) [5] Empatia - 1 (4,8\%) [6] Pomoc, gdy ktoś pomaga mi w realizowaniu celów, jest gotowy do pomocy, ktoś służy pomocą (chce pomóc), ktoś pomaga mi się odnaleźć w trudnej sytuacji - 7 (33,3\%) [7] Pozwala mi korzystać ze swojego doświadczenia i wiedzy- 1 (4,8\%) [8] Poczucie bezpieczeństwa - 1 (4,8\%) [9] Spokój- 1 (4,8\%) [10] Kiedy mogę porozmawiać o problemie, podczas rozmowy, rozmowa z przyjaciółmi - 5 (23,8\%) [11] Kiedy dostaję czas, ktoś ma dla mnie czas - $3(14,3 \%)$ [12] Kiedy dostaję uwagę - 1 (4,8\%) [13] Kiedy ktoś jest zaangażowany - 1 (4,8\%) [14] Wiara w powodzenie - $1(4,8 \%)$ [15] Gdy ktoś potwierdzi moje decyzje lub się do nich jakoś odniesie - 1 (4,8\%) [16] Gdy ktoś troszczy się o mnie - $1(4,8 \%)$ [17] Gdy ktoś dba o moje potrzeby - $1(4,8 \%)$ [18] Zaufanie - 1 (4,8\%) [19] Przyjaźń - 1 (4,8\%) [20] Nie ocenia, nie krytykuje, nie osądza - $3(14,3 \%)$ [21] Akceptacja - 1 (4,8\%) [22] Wyrażenie bezpieczne swoich emocji, obaw, odczuć - 1 (4,8\% [23] Ktoś wyraża zainteresowanie sprawą - 1 (4,8\%) [24] Gdy dostaję siłę do zmierzenia się z problemem - 1 (4,8\%) [25] Czuję, że nie jestem sama - 1 (4,8\%)

Uwaga: Terapeutki mowy podawały zazwyczaj więcej niż 1 znaczenie (kategorię), które nadawane było przez nie „wsparciu psychicznemu", a więc całość nie sumuje się do $100 \%$.

Please note that speech therapists usually attributed more than 1 meaning (category) to the „feeling supported”, so total result in not $100 \%$.

\section{Wsparcie emocjonalne $w$ doświadczeniach terapeutek mowy - „Czym jest dla mnie wsparcie emocjonalne?”, "Kiedy czuję się wspierana?" - pilotażowe badania jakościowe}

Podczas warsztatów poświęconych udzielaniu emocjonalnego wsparcia rodzicom dzieci z zaburzeniami słuchu pozostających w terapii logopedycznej [23] grupa terapeutek mowy została poproszona o anonimowe zapisanie na kartkach skojarzeń związanych ze wsparciem emocjonalnym, tj. „Czym jest emocjonalne wsparcie?” (tabela 1), a następnie, „Kiedy mam poczucie wsparcia, czuję się wspierana?" (tabela 2).

W badanej grupie najczęściej emocjonalne wsparcie kojarzone było $\mathrm{z}$ „pomocą" (różnie rozumianą), a następnie „uważnym słuchaniem”, „zrozumieniem”, „ukierunkowaniem, jakiego można oczekiwać”. Innymi słowy, pytanie o to, ,jak wspierać” rodzica dziecka głuchego, staje się pytaniem o to, jak mu pomagać, uważnie słuchać, okazywać zrozumienie i ukierunkowywać. Logopedzi, a także inni terapeuci, z taką reprezentacją emocjonalnego wsparcia 
będą je wnosić do relacji z drugą osobą: rodzicami. Pozostałe składowe wsparcia emocjonalnego, pojawiające się w wypowiedziach terapeutek-logopedek, związane są $\mathrm{z}$ emocjami, towarzyszeniem drugiej osobie, kontaktem z nią i współodczuwaniem. W percepcji badanych kobiet pozostają one niejako „w tle" procesu wspierania.

Z kolei te same terapeutki mowy na pytanie: „Kiedy czuję się wspierana?”, priorytetowe znaczenie przypisują „byciu z" drugą osobą, byciu fizycznemu, bliskiemu, obecności drugiego człowieka, w tym doświadczaniu „bycia z”, niekoniecznie werbalizowanemu, np. w rozmowie. Jeśli zatem kategoria „bycia z” nie zaistniała tak wyraziście w procesie nadawania znaczenia „wsparciu emocjonalnemu”, lecz dopiero podczas uruchamiania odczuć i myśli związanych $\mathrm{z}$ „poczuciem bycia wspieraną", można sądzić, że terapeuci mowy potrzebują profesjonalnego wsparcia i szkolenia w tym, jak sięgać do zasobów tkwiących w „pierwotnym”, „niewerbalnym” byciu z drugą osobą na rzecz emocjonalnego wsparcia rodziców dzieci głuchych (niepełnosprawnych). Ponadto takiego „bycia z" drugą osobą, które dla obu stron interakcji jest bezpieczne.

\section{Co sprzyja dawaniu vs. otrzymywaniu wsparcia emocjonalnego $\mathrm{w}$ relacji: terapeuta mowy - rodzic dziecka głuchego?}

Wsparcie emocjonalne $\mathrm{w}$ ramach terapii surdologopedycznej ma szansę zachodzić, gdy relacja między terapeutą mowy a rodzicem dziecka głuchego ma następujące właściwości:

- Jest relacją osobową.

- Role i zasady osób w niej uczestniczących zostały jasno określone (i zawarty został tzw. kontrakt).

- „Granice” wyznaczone zawartym kontraktem, a także rolami osób pozostających w tej relacji, są przestrzegane i zachowywane.

- Stosowane są zasady efektywnego komunikowania się z drugą osobą.

- Osoba udzielająca wsparcia emocjonalnego (terapeuta mowy lub inny terapeuta) nie zaprzecza istnieniu problemu (głuchocie, niepełnosprawności dziecka lub innym problemom) oraz doświadczanym przez drugą osobę (rodzica) stanom psychicznym i emocjom: cierpieniu, bezsilności, niemocy czy złości.

- Osoba udzielająca wsparcia emocjonalnego (terapeuta mowy lub inny terapeuta) umiejętnie korzysta $\mathrm{z}$ własnych doświadczeń i wiedzy o sobie.

\section{Osobowa relacja: terapeuta mowy (lub inny terapeuta) - rodzic dziecka głuchego}

Wsparcie emocjonalne otrzymujemy i dajemy w relacji z drugą osobą, relacji polegającej na wzajemnym zaufaniu, bezpiecznej, umożliwiającej wymianę emocji i myśli, którą można określić jako relację osobową [18]. Relację tę cechuje (wzajemny) szacunek, zrozumienie (docenienie) sytuacji drugiej osoby (rodziców), akceptacja, empatia. Osobowej relacji rodzica czy dziecka $\mathrm{z}$ terapeutą (psychologiem) towarzyszy zdaniem Zalewskiej [24] kontakt niedyrektywny, gdyż tylko $\mathrm{w}$ takim kontakcie $\mathrm{z}$ drugą osobą możemy być sobą, zaistnieć jako osoby. Można powiedzieć, że osobowa relacja terapeuty mowy $\mathrm{z}$ rodzicem dziecka głuchego (niepełnosprawnego) sama w sobie jest relacją wspierającą rozwój osoby (stanowi wsparcie emocjonalne).
Role i zasady w relacji: terapeuta mowy (lub inny terapeuta) i rodzic dziecka głuchego są jasno określone („kontrakt” między terapeutą mowy i rodzicem)

Jasno określone role: rola terapeuty mowy i rola rodzica dziecka biorącego udział w terapii surdologopedycznej, a także, co się z nimi wiąże, tj. przyjęte zasady związane $\mathrm{z}$ prowadzeniem terapii dziecka, zostają określone w zawartym kontrakcie terapeuty mowy $\mathrm{z}$ rodzicem dziecka. $\mathrm{Z}$ kontraktu tego powinny również wynikać obowiązujące zasady (np. punktualnego przychodzenia na terapię czy odwoływania spotkań z ważnych przyczyn, miejsca terapii, czasu jej trwania i częstości, obecności rodzica lub nie podczas prowadzonych sesji terapeutycznych $\mathrm{z}$ dzieckiem i wiele innych) przyjęte przez terapeutę mowy i rodzica dziecka głuchego. Jasno określone role i zasady, których zgadzają się przestrzegać obie strony kontraktu, stwarzają bezpieczne ramy dla prowadzenia terapii logopedycznej wobec dzieci głuchych (jak i z innymi problemami), a także ramy, w jakich udzielane jest wsparcie emocjonalne. Wykraczanie poza te ramy, wyznaczone przyjętym kontraktem (np. rozmowy telefoniczne $\mathrm{z}$ rodzicami poza ustalonymi terminami spotkań terapeutycznych), może stać się źródłem problemów zarówno po stronie terapeuty mowy, jak i rodzica.

\section{„Granice” w relacji: terapeuta mowy (lub inny terapeuta) - rodzic dziecka głuchego. Jak je zachować?}

Dbanie o to, by zachować granice w relacji terapeuty mowy $\mathrm{z}$ rodzicami, ściśle wiąże się $\mathrm{z}$ przestrzeganiem kontraktu terapeuta - rodzic, który tworzy ramy tej relacji, a przez to wspiera obydwie strony w ich utrzymywaniu. Mówiąc o zachowaniu granic, odnoszę się też do granic psychologicznych w omawianej relacji [17], jak np. ujawniana agresja, lekceważenie czy obrażanie terapeuty, dopytywanie o życie prywatne, a także zachowania manipulacyjne, które mogą ujawniać się w formie gróźb, szantażu w różnej formie czy uwodzenia, co zazwyczaj należy do zachowań świadczących o przekraczaniu granic. Wskazane jest, by przekraczanie granic, do jakiego dojść może w omawianej relacji terapeuta mowy - rodzic dziecka głuchego, terapeuta sygnalizował rodzicowi $\mathrm{w}$ momencie ich przekraczania, a więc „tu i teraz”.

\section{Efektywne komunikowanie się w relacji: terapeuta mowy (lub inny terapeuta) - rodzic dziecka głuchego}

Warunkiem efektywnego komunikowania się jest posiadanie przez terapeutę umiejętności słuchania klienta [17,25], którym staje się rodzic dziecka głuchego, a także świadome stosowanie strategii wspierających proces efektywnego komunikowania się z drugą osobą. Do strategii tych należą m.in. parafraza, klaryfikacja (wyjaśnianie) oraz konfrontacja „tu i teraz”.

Słuchanie klienta to proces aktywny, któremu towarzyszą zaangażowanie i zainteresowanie jego osobą. Jako słuchający przekazujemy komunikaty informujące drugą osobę (rodzica) o tym, że ją słuchamy, w formie krótkich potwierdzeń, jak np. aha, $\mathrm{mhmm}$, tak. Jednocześnie odwołujemy się do przekazów niewerbalnych, takich jak: kiwanie 
czy potrząsanie (potakiwanie) głową (niezbyt częste, aby nie sprawiało wrażenia sztuczności), postawa ciała (najczęściej osoby pozostające $\mathrm{w}$ dobrym kontakcie przyjmują podobne postawy ciała), wyraz twarzy, kontakt wzrokowy (porozumienie $\mathrm{z}$ drugim człowiekiem opiera się także na kontakcie wzrokowym, lecz tu też nie można przesadzić), bliskość fizyczna (każdy sam określa odległość, w jakiej dobrze się czuje), ton głosu [25]. W czasie aktywnego słuchania, o jakim tu mowa, istotne jest uwrażliwienie na słowa-pułapki, ujawniane na poziomie werbalnym, z tego względu, że utrudniają one słuchanie klienta, a co za tym idzie - efektywne porozumiewanie się z nim. Należą do nich (przykłady) [za: 17]:

Ty nie możesz tak postępować (nasza opinia, ocena).

To ci przeszkadza (mglistość komunikatu).

Oni są na ciebie zdenerwowani (mglistość komunikatu). Powinieneś więcej czasu poświęcić na rehabilitację córki (oskarżenie albo rada).

Zawsze jesteś nieprzygotowana do zajęć (w większości takie generalizacje są nieprawdziwe).

Istnieją techniki, których stosowanie wspiera efektywne komunikowanie się z drugą osobą. Należy do nich m.in. parafraza wypowiedzi rozmówcy (rodzica) $[17,26]$, czyli inaczej powtórzenie własnymi słowami jej treści (przykłady):

1) Terapeuta mowy: $Z$ tego, co mówisz (co Pani mówi), rozumiem, $\dot{z} e .$.

2) Terapeuta mowy: Czyli chodzi o...

3) Terapeuta mowy: Jak rozumiem, chciał Pan powiedzieć...

4) Terapeuta mowy: Innymi słowy..

5) Terapeuta mowy: Martwi się Pani, że jeszcze nie sq widoczne posteppy w rozwoju mowy u Ali.

Wyjaśnianie (klaryfikacja) [27] to technika pozwalająca na sprawdzenie (uściślenie, uporządkowanie wypowiedzi), czy terapeuta i klient (rodzic) dobrze się zrozumieli, tzn. czy terapeuta dobrze zrozumiał, co klient chciał mu przekazać:

1) Terapeuta mowy: Czy dobrze Pania rozumiem, że od czasu, kiedy mąż zaczął więcej pracować, Basia zaczęła mieć kłopoty $w$ przedszkolu?

2) Terapeuta mowy: $Z$ tego, co Pani powiedziała, wynika, że Adaś od jakiegoś miesiąca niechętnie nosi implant [ślimakowy] $w$ domu.

Konfrontacja to kolejna technika [27,28], którą można posłużyć się w celu efektywnego porozumienia $\mathrm{z}$ drugą osobą. Polega ona na konfrontacji klienta (rodzica) z zaobserwowanymi przez terapeutę emocjami i zachowaniem, co ma służyć uświadomieniu mu rozbieżności między zachowaniem a prezentowaną przez niego postawą.

1) Terapeuta mowy: Wygląda dziś Pani na przygnębioną, jakby coś się zdarzyło..

2) Terapeuta mowy: Mam wrażenie, że powstrzymuje sie Pani od płaczu, choć na moje pytanie, jak minął ten tydzień, odpowiedziała Pani, że dobrze.

3) Terapeuta mowy: Na ostatnich zajęciach powiedziała Pani, że Bartek $w$ domu nazywa części ciała. Dziś potrafi pokazać tylko głowe i oko misia...

Technik wspierających efektywne porozumiewanie się $\mathrm{z}$ drugą osobą jest wiele, a prezentują je liczne podręczniki poświęcone zagadnieniom pomagania i efektywnego komunikowania się w relacjach interpersonalnych.
Niezaprzeczanie przez terapeutę mowy (lub innego terapeutę) głuchocie dziecka

Specjaliści niejednokrotnie wspierają rodziców w zaprzeczeniu rzeczywistości, tworzeniu iluzji, stawiając na przykład zbyt optymistyczne prognozy i wzbudzając fałszywe nadzieje: „Będzie dobrze”, „Dziecko będzie mówiło”, „Nie takie ludzie mają problemy”, „On/ona jest przecież takim samym dzieckiem jak dziecko słyszące, niczym się nie różni, ma tylko niedosłuch".

Dlaczego tak się dzieje? By być otwartym i przyjąć cierpienie drugiej osoby, trzeba mieć dostęp do siebie, swoich emocji i cierpienia. Specjaliści (logopedzi, psychologowie, lekarze i inni), jakich spotykają na swej drodze rodzice dzieci głuchych, posiadają zróżnicowane możliwości konfrontacji z własnym, a tym samym cudzym, cierpieniem. Dlatego też czasem łatwiej jest im „oddać się iluzjom" (w które to sami często nie wierzą), niż skonfrontować rodzica $\mathrm{z}$ jego negatywnymi emocjami, bólem, cierpieniem, bezsilnością, rozpaczą czy niewiadomą, wobec jakiej stają. Eichelberger mówi o współodczuwaniu w relacji lekarz - pacjent, nie empatii, nie współczuciu, często kojarzonym z litością. Współodczuwanie jest „takim stanem serca i umysłu, który pozwala doskonale zorientować się w położeniu drugiej osoby i je zrozumieć, przy czym nie pozbawia nas możliwości skutecznego, pomocnego działania" [29, s. 134]. Przywołuje innego znanego psychoterapeutę, Miltona Ericksona, który zauważył, że „współodczuwanie nie polega na pocieszaniu, na uwodzeniu obietnicami, odwracaniu uwagi” - wręcz przeciwnie „te dość powszechne zachowania wskazują na deficyt współodczuwania, są wyrazem niechęci do wchodzenia w świat przeżyć cierpiącego człowieka" [29, s. 138].

\section{Osoba udzielająca wsparcia emocjonalnego (terapeuta mowy lub inny terapeuta) umiejętnie korzysta $z$ własnych doświadczeń i wiedzy o sobie}

Własne doświadczenia stanowią odniesienie, nie tylko w kwestii, jak to jest być wspieranym, lecz także związanych $\mathrm{z}$ doświadczeniem zawodowym $\mathrm{w}$ pracy $\mathrm{z}$ dziećmi głuchymi i ich rodzicami, także w relacji terapeuty mowy z rodzicem dziecka głuchego. Posługując się różnymi interwencjami (technikami efektywnego komunikowania się), logopeda może przywołać przykład ze swojej dotychczasowej praktyki, nie ujawniając żadnych faktów umożliwiających identyfikację innego dziecka czy rodzica, którego historię przywołuje w określonym celu. Celem takim może być chęć pokazania rodzicowi dziecka głuchego pewnej „obiektywnej” rzeczywistości, np. „dzieci o podobnych audiogramach mogą się zupełnie inaczej rozwijać w sferze mowy i języka" w odpowiedzi na często zadawane przez matki i ojców małych dzieci z głuchotą prelingwalną pytanie: „Czy moje dziecko będzie mówiło?”.

Współodczuwanie, o którym wcześniej już wspomniano, polega też na odwoływaniu się do własnych doświadczeń, lecz „związanych z cierpieniem i komunikujemy to doświadczenie w kontekście sytuacji, która właśnie się dzieje. (...) ale trzeba uważać, aby nie zapędzić się w opowiadanie o swoich doświadczeniach. Wtedy pacjent [rodzic - JK] poczuje się zlekceważony i odrzucony" [29, s. 140]. 
Wiedza o sobie przydatna w relacji terapeuty mowy z rodzicem to także świadomość własnych ograniczeń, np. nieumiejętności towarzyszenia osobie płaczącej czy trudności w radzeniu sobie z cudzą wrogością i agresją - wówczas terapeuta mowy może poszukać dla siebie profesjonalnego wsparcia, jak radzić sobie w takich sytuacjach, gdyż u ich podłoża leżą zazwyczaj własne nieprzepracowane doświadczenia emocjonalne. $\mathrm{W}$ takich sytuacjach może też poprosić o pomoc innego specjalistę, np. psychologa.

\section{Trudne sytuacje, trudne pytania, trudne zachowania rodziców dziecka głuchego - przykłady (możliwych) interwencji terapeutów mowy}

Podano poniżej kilka przykładów sytuacji, które mogą mieć miejsce w ramach terapii surdologopedycznej w relacji logopedy z rodzicem. Wybrane zostały te, które mogą być trudne, i zazwyczaj takimi są dla terapeutów mowy. Propozycji ich rozwiązań w formie efektywnych interwencji może być bardzo wiele. Terapeuta mowy z biegiem czasu i nabywaniem doświadczenia $\mathrm{w}$ kontaktach $\mathrm{z}$ rodzicami dzieci będących u niego w terapii uczy się wybierać te sposoby interwencji wobec rodziców, które jego zdaniem są trafne (co nie zawsze znaczy, że służą pozytywnemu rozwojowi rodzica), a także pozostają w zgodzie z nim samym, jako osobą i terapeutą mowy.

\section{PRZYKŁAD I}

Pytanie rodziców dotyczy przyczyn głuchoty dziecka. Niejednokrotnie powraca ono co jakiś czas i jest „od nowa” zadawane logopedzie prowadzącemu terapię surdologopedyczną:

Dlaczego moje dziecko ma wadę stuchu?

Dlaczego to nas spotkało? Nas dotknęto?

Przykładowe interwencje terapeuty mowy:

W takiej sytuacji łatwo o dokonanie oceny czy okazanie zniecierpliwienia, np. „Tyle razy już mówiłam, że przyczyna jest nieznana” albo „Proszę zapytać o to lekarza”, co raczej nie będzie sprzyjać porozumieniu i efektywnej wspierającej rodzica emocjonalnie wymianie $\mathrm{z}$ terapeutą mowy. W tym celu terapeuta mowy może wykorzystać np. parafrazę, technikę polegającą na powtórzeniu własnymi słowami treści wypowiedzi rodzica:

Terapeuta mowy: $Z$ tego, co Pani mówi rozumiem, że nadal poszukuje Pani odpowiedzi na pytanie o przyczyny głuchoty Tomka.

Matka: Tak, nie daje mi to spokoju...

Klaryfikacja, która polega na uściśleniu, co rozmówca (rodzic) miał na myśli, może stanowić kontynuację tego dialogu między terapeutą mowy a matką Tomka, może też być niezależną interwencją w opisywanej sytuacji.

Terapeuta mowy: Innymi słowy, odczuwa Pani niepokój nie znajac przyczyny gtuchoty swojego syna.

Matka: Tak, właśnie...

Konfrontacja przeżyć matki związanych z poszukiwaniem „przyczyny głuchoty dziecka” z jej zachowaniem „tu i teraz" podczas zajęć terapii surdologopedycznej, dokonana przez terapeutę mowy, może nastąpić jako kolejna interwencja w opisanej sytuacji, a także niezależnie - w odpowiedzi na opisane w tym przykładzie pytania rodzica (matki):

Terapeuta mowy: Nie znam odpowiedzi na to pytanie. Mam wrażenie, że niepokój, jaki Pani towarzyszy, utrudnia skupienie się na tym, co robimy $z$ Tomkiem. Czy nie tak? Matka: Troche ma Pani rację. Moje myśli co jakiś czas wędruja gdzie indziej, poza ten gabinet. Zastanawiam się, dlaczego to mnie spotkało.

Terapeuta mowy: Czego Pani teraz potrzebuje, abyśmy mogli kontynuować zajęcia?

Matka: Pocieszenia, nadziei, że dam sobie radę.

Terapeuta mowy: Rozumiem, $\dot{z}$ e jest to Pani bardzo potrzebne.

Pocieszenie, o które „dopomina się” matka, przyjęło się potocznie uważać za pomoc w trudnej czy beznadziejnej sytuacji. Jednakże, aby poczucie beznadziejności, rozpaczy czy silnego niepokoju przeminęło, musi „albo zmienić się sytuacja będąca tego przyczyną, albo pojawić się przynajmniej takie zrozumienie tej sytuacji, które umożliwi podjęcie prób jej zmiany” [30, s. 15]. Mówiąc: „Będzie dobrze, wszystko się ułoży, proszę się nie martwić”, a więc „pocieszając, idziemy na ogół na skróty - udajemy, że mamy rozwiązanie, którego na razie nie mamy ani my, ani nie zna go nasz rozmówca" [30, s. 15]. Z tego też względu bardziej konstruktywne dla osoby pragnącej pocieszenia, innymi słowy emocjonalnego wsparcia, jest posłużenie się którąś z omawianych wcześniej technik efektywnego komunikowania się $\mathrm{z}$ drugą osobą.

\section{PRZYKŁAD II}

Pytania rodziców dotyczą prognoz w sferze rozwoju mowy i języka dziecka głuchego i jego dalszej przyszłości:

Czy moje dziecko będzie mówiło?

Czy moje dziecko będzie się rozwijało jak słyszący rówieśnicy? Czy będzie normalnie żyć?

Czy założy rodzinę?

Przykładowe interwencje terapeuty mowy:

Konfrontacja „tu i teraz” - terapeuta mowy dokonuje oceny rozwoju mowy i języka dziecka głuchego na „tu i teraz” (co pewien czas może tej oceny dokonywać, a tę kwestię także ustala $\mathrm{z}$ rodzicem $\mathrm{w}$ zawartym $\mathrm{z}$ nim kontrakcie). Terapeuta mowy dokonuje opisu etapu rozwoju mowy i języka, na jakim aktualnie znajduje się dane dziecko głuche (podając liczne, konkretne przykłady), oraz odnosi czynione obserwacje do wiedzy o rozwoju mowy i języka dziecka słyszącego o typowym rozwoju (oraz jeśli uzna za wskazane odnosi poczynione obserwacje do rozwoju mowy dzieci głuchych ze swojego doświadczenia).

Odwołanie się do wiedzy i własnych doświadczeń - terapeuta mowy stosuje interwencję polegającą na tym, że odwołuje się on do własnego doświadczenia:

Terapeuta mowy: Myślę, że...

Terapeuta mowy: $Z$ mojego doświadczenia wynika, że dzieci o podobnych możliwościach słuchowych jak Pani 
syn/córka osiągaja zróżnicowany poziom kompetencji językowych.

Klaryfikacja - interwencja z zastosowaniem strategii, jaką jest klaryfikacja, polegająca na opisaniu i nazwaniu swoimi słowami przez terapeutę mowy wypowiedzi rodzica, może mieć miejsce w odpowiedzi na różne pytania rodziców zadawane w najróżniejszych sytuacjach:

Matka: Co by Pani zrobiła na moim miejscu?

Terapeuta mowy: Rozumiem, że się Pani niepokoi, co będzie dalej. Myślę, że teraz trzeba się skupić na obecnym etapie rozwoju mowy i języka.

\section{PRZYKŁAD III}

Rodzice prezentują „trudne zachowania”, np. ujawniają silne negatywne emocje czy osobiste problemy wobec terapeuty mowy:

Matka: Wiem, że nie pracuję $z$ Małgosia tyle, ile potrzeba... Ale nie daję rady. Mąż rzadko bywa $w$ domu, późno wraca, nawet nie zapyta, jak tam Małgosia, czeka na efekty rehabilitacji. Moi rodzice sa daleko i pomóc mi nie moga. Boje się, że jak tak dalej pójdzie, to mąż znajdzie sobie inna kobietę. Niech mi Pani poradzi, co mam zrobić. Co by Pani zrobiła na moim miejscu?

Przykładowe interwencje terapeuty mowy:

\section{Klaryfikacja}

Terapeuta mowy: Rozumiem, że jest to dla Pani bardzo trudna sytuacja. Czego Pani teraz ode mnie potrzebuje? Matka: Chce, by Pani zrozumiała, jak ja się czuję...

Inne możliwe sposoby interwencji:

Terapeuta mowy: Nie wiem, co bym zrobiła na Pani miejscu. Myślę, że gdyby to mnie dotyczyło, starałabym się porozmawiać szczerze $z$ mężem o tej całej sytuacji, o której przed chwila mi Pani opowiedziała.

Terapeuta mowy: Czy chce Pani jeszcze coś na temat powiedzieć?

Terapeuta mowy: Czy możemy przejść do dalszej części zajęć?

Terapeuta mowy: Czy myślała Pani o spotkaniu z psychologiem (psychoterapeuta), by się przyjrzeć temu, co dzieje się $w$ Pani życiu?

Rodzic często może prosić o radę i prowokować do ich dawania czy różnych form „pouczeń”.

Rady jednak nie należą do efektywnych strategii w komunikowaniu się, a tym samym nie są tym, o co proszącemu o nie na ogół chodzi. Często bywają nietrafione, zwłaszcza pouczenia takie jak: „weź się w garść”, „zdaj się na los” czy „zobacz, co czas pokaże” są najczęściej mało skuteczne bądź w ogóle nieskuteczne. Osoba dostająca je, $\mathrm{w}$ omawianym przypadku jest nią rodzic dziecka głuchego, „pouczenie łatwo potraktuje jako negatywną ocenę własnej osoby, co wzmocni tylko poczucie własnej bezradności” [30, s. 24].

\section{PRZYKŁAD IV}

Rodzice prezentują „trudne zachowania”, np. zgłaszają „roszczenia”, pretensjie czy nierealistyczne oczekiwania wobec terapeuty mowy:

Matka: Robię, co mi Pani zaleca, ale Kasia jeszcze nic prawie nie mówi. Może Pani zmieni metodę pracy, bo ile można czekać na jakieś efekty?

Przykładowe interwencje terapeuty mowy:

\section{Klaryfikacja}

Terapeuta mowy: Rozumiem, że chciałaby Pani szybkich postępów... Metoda, która pracuję, ma swoje zasady i podjęła Pani decyzję, że będziemy razem pracować ta metoda z Kasią. Co ma Pani na myśli, jeśli chodzi o „zmiane metody"?

Matka: Nie o sama metodę mi chodzi, lecz o postępy Kasi. Dzieci słyszace w jej wieku ładnie buduja zdania.

\section{PRZYKŁAD V}

Rodzice prezentują postawę i oczekiwania, że efekty terapii logopedycznej mają wynikać przede wszystkim z pracy terapeuty mowy $\mathrm{z}$ dzieckiem, a nie $\mathrm{z}$ ich zaangażowania i wspierania dziecka w nabywaniu mowy i języka (wychowania językowego) pod kierunkiem terapeuty mowy.

Rodzic: Może byśmy częściej do Pani przychodzili? Wtedy może bylyby $i$ jakieś wyniki rehabilitacji Zosi. Co to jest, spotkanie raz na tydzień..

Przykładowe interwencje terapeuty mowy:

\section{Klaryfikacja}

Terapeuta mowy: Rozumiem, że chciałaby Pani częściej przychodzić z Zosia na zajęcia logopedyczne. Nie ma jednak takiej możliwości - w tym ośrodku pracujemy w systemie cotygodniowych spotkań, jednogodzinnych.

Matka: To bardzo mało, jeśli chodzi o zajęcia dla takiego dziecka. Trudno sie dziwić, że efekty sa niewielkie skoro Pani ma czas dla dziecka tylko godzinę, raz na tydzień. Terapeuta mowy: $W$ tym sposobie prowadzenia terapii surdologopedycznej to rodzic dostaje od logopedy wskazówki $i$ instruktaż do pracy $z$ dzieckiem $w$ domu. $Z$ mojego doświadczenia wynika, że ta metoda terapii logopedycznej przynosi dobre i bardzo dobre rezultaty, ale warunkiem jest praca rodziców $z$ dzieckiem $w$ domu.

Inne możliwe sposoby interwencji:

Terapeuta mowy: Co ma Pan/Pani na myśli, mówiac, że „wtedy może bylyby i jakieś wyniki rehabilitacji Zosi”?

Rodzic: Nie umiem, tak jak Pani to robi, prowadzić z córka tych ćwiczeń $w$ domu. Jakoś mi to nie wychodzi.

Terapeuta mowy: Czego Pani potrzebuje ode mnie, aby dzisiejsze zadanie zrobić $z$ Zosia $w$ domu?

Rodzic: Chciałabym zobaczyć, jak inni rodzice sobie radzą.

Przykładów interwencji logopedów wobec rodziców dzieci głuchych pozostających u nich w terapii, tych rodziców 
którzy są zdania, że to logopeda ma pracować z dzieckiem, a nie rodzic (co komunikują wprost lub pośrednio) - może być wiele. Dużo zależy od tego, jak terapeuta mowy spostrzega przyczyny takiego stanowiska i zachowania rodziców. Czy odbiera je jako niechęć („skąd się ona bierze?”), czy traktuje jako wyraz niezrozumienia procesu nabywania języka przez dzieci z głęboką wadą słuchu. Bywa, że przypisuje takim rodzicom „wygodnictwo” albo trudności w radzeniu sobie $\mathrm{z}$ głuchotą dziecka. Każdy z pomysłów, dlaczego tak się dzieje, należałoby sprawdzić w konfrontacji z rodzicem, jeśli to możliwe. Umożliwia to wykorzystywanie strategii efektywnego komunikowania się w relacji terapeuty mowy z rodzicem dziecka głuchego.

\section{Wnioski}

W odniesieniu do rodziców dzieci głuchych i słabosłyszących bardzo ważnym zagadnieniem jest wsparcie emocjonalne, którego potrzebują, aby psychicznie stawać się rodzicami swoich głuchych i słabosłyszących dzieci. $Z$ tego względu, że specjaliści uczestniczący w rehabilitacji słuchu i mowy stanowią dla nich niezwykle ważne źródło wsparcia, także emocjonalnego, należałoby stworzyć im możliwości psychoedukacji i szkolenia na temat: „jak dobrze wspierać rodziców”, pozostając w zgodzie ze sobą i pełnioną zawodową rolą. Konstruktywne wsparcie emocjonalne dawane rodzicom przez terapeutów mowy nie zawsze wiąże się z doświadczaniem przez rodziców pozytywnych emocji, „zgadzaniem się" $z$ ich poglądami czy miłą atmosferą, lecz jego celem jest dobro rodzica i jego głuchego dziecka.

Wskazana byłaby organizacja treningów służących rozwojowi podstawowych umiejętności interpersonalnych w relacji pomagania, jaką jest relacja logopedy (czy innego specjalisty) $\mathrm{z}$ rodzicem $\mathrm{w}$ ramach terapii surdologopedycznej dziecka. W dalszej kolejności pomocne byłyby superwizje prowadzone pod kątem relacji, jaką nawiązuje terapeuta mowy $\mathrm{z}$ rodzicem, czy organizacja grup $\mathrm{Ba}$ linta ${ }^{2}$ lub innych form wsparcia, edukacji i rozwoju dla tej grupy zawodowej.

\section{Piśmiennictwo:}

1. Kondracka-Szala M. Wsparcie społeczne osób stygmatyzowanych Wirtualne grupy samopomocowe. Warszawa: Difin SA; 2015.

2. Sęk $\mathrm{H}$. O wieloznacznych funkcjach wsparcia społecznego. W: Cierpiałowska L, Sęk H, red. Psychologia kliniczna i psychologia zdrowia. Wybrane zagadnienia. Poznań: Wydawnictwo Humaniora; 2001

3. Heszen I. Psychologia stresu. Warszawa: Wydawnictwo Naukowe PWN; 2013.

4. Carver CS. You want to measure coping but your protocol's too long. Consider the Brief COPE. Int J Behav Med, 1997; 4(1): 92-100.

5. Kobosko J. Rodzice dziecka głuchego wobec różnych form pomocy psychologicznej - dlaczego trudno po nie sięgać? W: Gałkowski T, Radziszewska-Konopka M, red. Wspomaganie rozwoju małego dziecka z wadą słuchu. Warszawa: Polski Komitet Audiofonologii; 2011, 143-56.

6. Kobosko J. Pomoc psychologiczna słyszącym rodzicom a efektywność rehabilitacji dziecka głuchego. Otorynolaryngologia - przegląd kliniczny, 2011; 10(1): 8-14.

7. Zalewska M. Pomoc psychologiczna słyszącym rodzicom dziecka głuchego. W: Siedlecka H, Kulczycka E, red. Współczesne kierunki wczesnej diagnozy i wczesnej rewalidacji dziecka z wadą słuchu. Warszawa: Wydawnictwo APS; 2000, 33-36.

8. Odzimek B. Pomoc psychologiczna rodzinom dzieci z uszkodzeniami słuchu. Potrzeby a rzeczywistość. W: Krakowiak K, Dziurda-Multan A, red. „Nie głos, ale słowo...”. Przekraczanie barier w wychowaniu osób z uszkodzeniami słuchu. Lublin: Wydawnictwo KUL; 2006, 303-14.

9. Dromi E, Ingber S. Israeli mothers' expectations from early intervention with their preschool deaf children. J Deaf Stud Deaf Educ, 1999; 4(1): 50-68.
10. Kobosko J. Tożsamość macierzyńska matek słyszących młodzieży głuchej i jej znaczenie dla rozwoju osobowej tożsamości tej młodzieży. Nieopublikowana rozprawa doktorska. Warszawa: Uniwersytet Warszawski, Wydział Psychologii; 2007.

11. Baran J. Problemy i konteksty wychowania dzieci z uszkodzonym słuchem w przekazach ich słyszących matek. Kraków: Wydawnictwo Naukowe UP; 2012.

12. Quittner AL, Glueckauf RL, Jackson DN. Chronic parenting stress: moderating versus mediating effects of social support. J Pers Soc Psych, 1990; 59: 1266-78.

13. Jackson CW. Family supports and resources for parents of children who are deaf or hard of hearing. Am Ann Deaf, 2011; 156(4): 343-62.

14. Kosmalowa J, Kobosko J. Grupa wsparcia dla rodziców dzieci z wadą słuchu. Szkoła Specjalna, 2002; 3: 174-80.

15. Kornaś D. Grupa wsparcia jako forma pomocy rodzinie dziecka niepełnosprawnego. W: Antoszewska B, Kossakowski C, red. Uwarunkowania i kierunki rozwoju pedagogiki specjalnej. Toruń: Wydawnictwo Adam Marszałek; 2011.

16. Borowicz A. Stres rodziców wychowujących dzieci z niepełnosprawnością słuchową. Niepełnosprawność - zagadnienia, problemy, rozwiązania, 2012; 3: 55-80.

17. Drat-Ruszczak K, Drążkowska-Zielińska E. Podręcznik pomagania. Podstawy pomocy psychologicznej. Szkoły i kierunki psychoterapii. Warszawa: Wydawnictwo SWPS Academica; 2005.

18. Rogers CR. O stawaniu się osobą. Tłum. Karpiński M. Poznań: Wydawnictwo Rebis; 2002.

19. Muñoz K, Nelson L, Blaiser K, Price T, Twohig M. Improving support for parents of children with hearing loss. Provider training on use of targeted communication strategies. J Am Acad Audiol, 2015; 26: 118-27.

\footnotetext{
2. Grupy Balinta - nazwa grup pochodzi od nazwiska ich twórcy M. Balinta. Pierwszą utworzył on w 1950 roku w Londynie. Grupy te mają na celu uświadomienie lekarzom ogólnym psychologicznych aspektów relacji z pacjentami oraz psychologicznego podłoża wielu problemów, z jakimi zgłaszają się pacjenci. Współcześnie prowadzone są przez przeszkolonych lekarzy lub psychologów klinicznych nie tylko dla lekarzy, lecz także dla innych grup zawodowych, np. pielęgniarek i innego personelu medycznego. Uczestnicy zapoznają się z wiedzą teoretyczną i uczą się praktycznie rozpoznawania reakcji emocjonalnych, postaw i wzorców zachowań w kontaktach z pacjentem.
} 
20. Zalewska M. Psychologiczne aspekty stwierdzenia głuchoty u dziecka. W: Rola J, red. Wybrane problemy psychologicznej diagnozy zaburzeń rozwoju dzieci. Warszawa: Wydawnictwo Akademii Pedagogiki Specjalnej; 1998.

21. Kobosko J. Depresja matek i ojców a głuchota dziecka. Znaczenie satysfakcji małżeńskiej jako predyktora. Roczniki Pedagogiczne, 2013; 3: 123-40, www.ceeol.com.

22. Broggi MA, Sabatelli R. Parental perceptions of the parent-therapist relationships: effects on outcomes of early intervention. Phys Occup Ther Pediatr, 2010; 30(3): 234-47.

23. Pankowska A, Zgoda M, Lutek A, Barej A. Sprawozdanie z III Konferencji Naukowo-Szkoleniowej „Słucham, więc potrafię” (Listening is „I can”) - terapia audytywno-werbalna. Czas posłuchać, 30.11.2012 r., Kajetany. Nowa Audiofonologia, 2013; 2(1): 87-90.
24. Zalewska M. Dziecko w autoportrecie z zamalowaną twarzą. Psychiczne mechanizmy zaburzeń rozwoju tożsamości dziecka głuchego i dziecka z opóźnionym rozwojem mowy. Warszawa: Jacek Santorski \& CO Wydawnictwo; 1998.

25. Geldard K, Geldard D. Rozmowa, która pomaga. Podstawowe umiejętności terapeutyczne. Gdańsk: GWP; 2004.

26. Szustrowa T, red. Swobodne techniki diagnostyczne. Wywiad i obserwacja. Warszawa: Wyd. Uniwersytetu Warszawskiego; 1991.

27. Mayerscough PM, Ford M. Jak rozmawiać z pacjentem? Gdańsk: GWP; 2002.

28. Kottler J. Opór w psychoterapii. Jak pracować z trudnym klientem? Gdańsk: GWP; 2003.

29. Eichelberger W, Stanisławska IA. Być lekarzem, być pacjentem. Rozmowy o psychologii relacji. Warszawa: Wydawnictwo Czarna Owca; 2013.

30. Jedliński K. Jak rozmawiać z tymi, co stracili nadzieję. Warszawa: Wydawnictwo W.A.B.; 1997. 